\title{
Further Reflecting on the Six-Year Primary Project of the Institute of Education, Uni- versity of Ife: The Key Players
}

\author{
Toyin Falola \\ University of Texas at Austin \\ toyinfalola@austin.utexas.edu \\ Michael Oladejo Afolayan \\ M\&P Educational Consulting International \\ Osogbo, Nigeria and Springfield, Illinois \\ mafolayan@yahoo.com
}

African linguistic complexity is often defined in terms of its multilingualism and a complicated colonial sociolinguistic heritage. This colonial heritage is seen in the prevalence of European languages, especially English and French, in the lingual franca of sub-Saharan states. A corollary to the latter assertion is that education in Africa, south of the Sahara, is primarily Eurocentric and quite unAfrican in context. More often than not, it is disempowering rather than empowering if we go by Paulo Freire's notion of education as being central to empowerment and poor education as the primary agent and metaphoric vehicle for modern day disempowerment, a knowledge base that does not liberate the mind or embrace the cognitive progression of the learner. ${ }^{1}$ After all, the original goal of colonial education was to train the "natives" in European languages so as to be able to communicate with and, ipso facto, serve their colonial "masters," and help him to rule the same "natives." The proverbial "Food for the slave" is relevant here; and as the saying goes, "it

1 See the following works of Freire: Faundez, Antonion, and Paulo Freire (1992). Learning to Question: A Pedagogy of Liberation. Trans. Tony Coates, New York, Continuum; Freire, P. and A.M.A. Freire (1994). Pedagogy of Hope: Reliving Pedagogy of the Oppressed. New York, Continuum; Freire, P. (1997). Mentoring the mentor: a critical dialogue with Paulo Freire. New York, P. Lang; and Freire, P. and A.M.A. Freire (1997). Pedagogy of the Heart. New York, Continuum. 
is not given to provide the slave nourishment or enhance good growth, but to provide just enough energy to keep on serving the malevolent master." Such is the unfortunate paradigm that captures the essence of colonial education in which the lingua franca of the indigenous learner is not only backgrounded but altogether demonized in some cases. Otherwise, how else could the common warning in the typical colonial classroom "Vernacular speaking is prohibited"? The so-called "vernacular" in question is the Yoruba language!

Strategies in the last few decades to correct this orientation distortion targeted knowledge indigenization. This was not a political statement; it was to face head-on the reality and efficacy of the power of the child's mother tongue. Mother Tongue Education (MTE) project at the Institute of Education, University of Ife, Ile-Ife, (now Obafemi Awolowo University) Nigeria, in which the Yoruba language constituted the medium of instruction and communication was considered a practical attempt at challenging this issue of indigenization. It was said to be the first of such experimentation in all of the African continent. The experiment drew a modern-day renaissance of practical application of the indigenous epistemology, attracting a jamboree of intellectuals whose sociological, cultural and professional orientations had informed them of the unparalleled cognitive power entrenched in Mother-Tongue education. This, of course, raised (and has always raised) fundamental and sociolinguistic questions with folks interrogating the empiricism of what they considered as such radically anti-progressive pedagogy, among many other factors. It is a well-known fact that the notion of the "anti-progressive" is just a political metaphor for any non-Western model of education, as the fact is well documented that education that draws from an organic and intuitive pool of knowledge can only be progressive because of its tendency to liberate the mind, providing culturally relevant pedagogy.

It was against this backdrop of cynicism and prejudice against non-Western pedagogical models that the idea of the Yoruba MT education was birthed. In looking at the lives of the principal proponents of, and actors on, this indigenous epistemology, we conclude that the Yoruba Mother-Tongue education was not an accident. Rather, it was an intentional undertaking precipitated by life experiences of its proponents. And, as earlier hinted, the individuals charged with the origination of the project saw the practical need for it on the bases of their own intuitive knowledge of the Yoruba education processes even prior to their exposures to the Western citadel of education, as well as theoretical and psychological principles that underlie the significance of the mother tongue in the cognitive process and education of the child. To this end, an ethnographic view of some of the key players in the project would be in order.

Our focus in this segment, therefore, is to zero in specifically on some of the keey participants in the project. This is partly because sometimes it is easy 
to pay attention to an aspect of history without putting in the foreground makers of such history, whereas the essence of a history and its originator/s are not mutually exclusive. And so, in the next few paragraphs, we put in proper perspective human elements by identifying some of the key personalities that made the Six-Year Primary Project possible. A closer examination of their backgrounds would shed a deeper insight into our understanding of their passion for the project and why their preferred model had and still have validity for knowledge empowerment. We should add that many of these pioneer educators no longer occupy major spaces in Yoruba education, and indeed, most of them have passed away, yet they left behind a treasure trove of knowledge in Yoruba education that generations after them could make use of in their quests for a viable mother tongue education in Yoruba.

Looking through the unpublished paper of Adebisi Afolayan (cir. 1970), we highlight four among the following personalities listed: A. Babs Fafunwa (Institute of Education); I. O. Delano (Institute of African Studies); Adebisi Afolayan (English Department); J. Y. K. Kerr (Institute of Education); D. S. Oke (English [later Linguistics] Department); J. R. Huntington (Department of Education); A. Salami (English Department); J. A. F. Sokoya (Department of Education); A. Laosebikan (Institute of African Studies); J. Macauley (Department of Education); B. Osibodu (Department of Education); A. Adaralegbe (Department of Education); J. O. Ogunlade (Department of Education); A. O. Euba (Institute of African Studies); F. A. Irele (Institute of African Studies) and the headmaster and staff of St. Stephen's 'A' Project, Modakeke School, Modakeke.

Before highlighting the individual actors in the Yoruba project, it is pertinent to look at the literature that informed the group of the salience of the project. Fafunwa, et al (1989), in their seminal work on the subject, for example, provide a preponderance of evidence to make a case for the need for a Mother Tongue education, and argument that propelled them into the need for this project. In it, they decry what they call "educational anachronism in Africa." Eleven scholars/educators contributed to this work. A. Babs Fafunwa, for example, focused on science and teacher education; Adebisi Afolayan addressed the issue language education; E. A. Yoloye wrote on the principles of evaluation; J.A.F. Sokoya wrote on thee social and cultural studies; Juliet Macauley focused on English and teacher. Education; A. M. Laosebikan talked about mathematics; D. Agbo Ologunde's chapter dealt with Yoruba language and book production; A. A. Taiwo wrote on science; A. Ojerinde and T. O. Fatokun focused on evaluation; while J. O. Folayan wrote on science. The crux of the whole work is to highlight the power of mother tongue education and how the Ife experiment underscored the need for such piloting to gain acceptance and become the norm of educational practice in the continent of 
Africa. In what follows, we take an extended excerpt from the authors' book. According to them,

The major aim of primary education is to help the child develop his natural abilities by creating the necessary environment that will stimulate, challenge and involve him socially, physically, intellectually and emotionally in the art of learning and doing. To this end, it is the responsibility of the educational system to facilitate learning by creating the ideal situation for the child to discover things for himself.

It is also universally agreed that a child learns best in his or her mother tongue. Yet, of all continents and peoples of the world, it is only in Africa and perhaps in a few other ex-colonial countries that former education is offered in a language that is foreign to the child.

In Europe, North America, USSR, China and in all other leading countries of the world, the child goes through the primary, secondary, and university education in his own mother tongue. In such countries, activities related to trade, commerce, education, civics, cultural and social aspects are conducted in the mother tongue. However, in Africa, south of the Sahara and north of the Limpopo, we educate our children practically in a foreign language from primary to post-secondary level. While some of the native speakers of English or French have problems in understanding their own language as dramatized in a popular book entitled: Why Jonny Can't Read, the African child has all of Jonny's linguistic problems plus his own, thus suffering from double jeopardy.

The African society of today is in an ambivalence position and so is the child from this environment. Between the ages 0 and 5, African children are invariably brought up in the traditional African environment, but when they reach the age of 6 , on third to one tenth of these children (depending on the African country) enter another educational system almost completely different from the one they were accustomed to; that is, they grew up with a certain cognitive style and suddenly found themselves in another environment with an entirely different approach. This phenomenon has not been given the attention it deserves by African educators and psychologists: we tend to assume that the African child takes dramatic change in his stride and we expect him to respond to this new environment as an average English, American or. German child would. The fact of the matter however is that the child's cognitive equilibrium has been disturbed and this abnormal situation (the deep gulf between traditional non-formal 
African system of education and the formal, Western oriented system of Education) tends to retard thee cognitive process in terms of. Of the anticipated outcome of the Western form of education. More than fifty per cent of the children who entered primary schools dropped out before the end of the course.

A number of studies carried out on 'Primary School dropouts' in Nigeria attributed the dropout phenomenon which ranges from 40 t0 60\% to:

(i) premature introduction of English as a language of instruction at the primary school;

(ii) poorly trained teachers; and

(iii) inadequate teaching and learning facilities

There is no continuity between the African child's home experience and the school experience - a situation that does not arise in the Western countries where in most cases, the child's school experience is a continuation of his home experience and exposure (p.7-9)

Fafunwa's and his team of writers went ahead in the book to make a componential analysis of this problem by juxtaposing the limitations and gains of the preschool child within the various cultural experiences, including when exposed to "Indigenous Home and Environment"; "Partly Indigenous and "Partly Western Home and Environment"; and Western-Oriented Home and Environment." Activities compared include (1) Play and Games; (2) Language used; and (3) Early exposure to Western education. The difference is clear. The Yoruba child with an early exposure to education in the Western medium of instruction will suffers significant cognitive and cultural consequences as opposed to when early childhood education is based only on the child's mother tongue.

In a related work, Adebisi Afolayan (2009) speaks to the centrality of language and culture in the delivery of an effective curriculum of science and technology generally and more specifically in Africa. He provides seven points as to the symbiotic relationship between language and culture on one hand and a curriculum for designed for a sustainable indigenous science and technology. The points raised are:

1. Language is the central instrument of human individual and societal development because it has a symbiotic relationship with culture, the totality of human experience shared by members of any community. 
2. Language is the only known road to human thinking, thee instrument that makes human "society" possible, and therefore, the indispensable tool for human development.

3. Knowledge is explored, discussed and extended by means of language. Thus. A man. Can conceive what a herd of elephants can do, although he has probably never. Seen more than a picture of one or two.

4. Language is the most powerful weapon of a community or society of men. On the one hand, it makes it possible for men to pool their thinking resources. On the other hand, it makes it possible for a strong leader to wield power or authority over other men in such a way that they do his bidding and achieve what he wants even against the original intention of those other men who are his followers.

5. Language endows man with three capacities that make development possible: originality, positive self-image and initiative.

6. Human societies are naturally monolingual-monocultural and monolingualism-monoculturalism is the agent of most human development so far.

7. Multilingual-multicultural Africa is still under-developed primarily because it has. Failed to capitalize positively upon and utilize its many languages in appropriate inter-relationships.

A. Babs Fafunwa: Fafunwa was a renowned professor of education and director of the Institute of Education at the then University of Ife (now Obafemi Awolowo University) in Ile-Ife. As a leading voice of mother tongue education around the nation, he chaired the advisory board of the project. Professor Aliyu Babatunde Fafunwa, popularly known as "Babs Fafunwa" was born into the Onikoyi Chieftaincy family of Isale Eko on September 23, 1923. His childhood experience included working as a fisherman in Jebba alongside his father who was a fisherman by trade. His would fall snugly into what John Dewey termed "instrumental pragmatism" in that his veering into education and eventually becoming an advocate for traditional and informal education could be traced to his organic acquisition of knowledge through watching the characteristic fisherman's hustling of his own father and other professional experiences down the road.

The need to deemphasize formal education and the common Western style pen-and-paper testing model and educational philosophy prompted Fafunwa's interest in holistic education, where emphasis is placed on the whole child rather than the formal and rigid teacher-oriented methods. We cannot detach his interest in education from his political stance. This nudged him into a higher education pursuit in the United States in the late 1940s, obtaining a combined Bachelor of Science degree in Social Sciences and English with an M.A. degree in English Education, plus $\mathrm{PhD}$ in Administration and Higher 
Education. Returning home, he chose to work with Esso, where he found that it was mainly run by the Whites.

It must be mentioned also that Fafunwa's interest in nation building came as a result of his rejection of the white colonial expatriates' domination of the workforce in Nigeria, and the fact that many of those white people did not have paper qualifications but learned on the job and became experts in their areas. In spite of his amassment of multiple formal academic degrees in the western citadel of learning, it sounds paradoxical that Fafunwa became an ardent proponent of Mother-Tongue education in Yoruba only using the English language as a second language. Mother-Tongue education was something that Fafunwa considered to be the only solution to the disempowering model of education and the education that could facilitate scientific and technological breakthroughs for any society or people. He felt the use of MT would facilitate three things:

1. deliver the student from the shackles of colonialism;

2. Allow for effective and meaningful communication between the teacher and student within and outside the classroom, and

3. Promote the development of mature judgement by the pupils.

Fafunwa was a teacher at all levels of education - elementary, secondary and tertiary levels. He was a scholar overseas and at home - University of Nigeria, Nsukka, University of Ibadan, and University of Ife were the three institutions where he served as lecturer and administrator. It was while at Ile-Ife that the birthing of the Six-Year Yoruba Primary Project took off and took shape.

In addition to several positions in academia at academic and administrative levels, Fafunwa's service to the nation included being Minister of Education from 1990-1992, and for his immeasurable service to the nation, he was a recipient of the Nigerian National Merit Award (NNMA) in 1989, and Commander of the Order of the Niger (CON) in 2002. Fafunwa died October 11, 2010 in Abuja, Nigeria.

Adebisi Afolayan: ${ }^{2}$ Afolayan is one of the surviving members of the originators of the Yoruba projects. He is a highly distinguished multidisciplinary intellectual - one of a rare type in modern times. Afolayan would remain among those leading voices whose vision of the Mother-Tongue education was, and still is, non pareil.

2 Information based on documents and personal knowledge of Professor Adebisi Afolayan. 
There is no definitive record of his birth but it is assumed he was born between 1927 and 1931. Born and raised early in life in the town of İrèsì, the northeastern settlement of Osun State, a multilingual confluence community with a dialectical amalgamation and permutation of Ijesa (via Igbajo and Otan Aiyegbaju), Ekiti (via Koro and Imesi-Ile), Igbomina (via Ila Orangun and Ora), Oyo-Osun (via Eripa and Iree)], the intuitive drive towards linguistic intellection and interlocutrice philosophy was natural. Like Fafunwa, native ingenuity with predisposition for informal education and knowledge acquisition came as an instinctive drive for Afolayan since he attended meetings and accompanied elders to campaigns being the grandson of the person with the combined title of the Oluode, head of the guild of hunters and Balogun, the titled warlord and field Marshall of the town. He learned at the feet of his elders and mastered the skills that were apparently over and above his contemporaries and so many of his views were so unique and too complicated for many of his peers to comprehend. His youthful exposure to numinous data of words and abstract knowledge drove him into an early life of strong non-western education. When he finally was introduced to western education at his latter youthful years, he was dubbed "Àję İwé" a child prodigy whose knowledge was seen as "supernatural." As fate would have it, Afolayan went through every stage of education - standard school, teacher training college (auxiliary, grade three, grade two, and grade one), obtained diplomas and certificates in linguistics, psychology, mathematics, social studies, etc. At the University College of London in Ibadan and London, where he studied for higher diploma, Bachelor of Arts, and doctorate of philosophy in English. His research titled, "The Linguistics Problem of Yoruba Learners and Users of English" cumulated into over one thousand pages of research dubbed as the longest $\mathrm{PhD}$ thesis ever written on the subject of the English language.

As lecturer and later professor and head of the Department of English at the then University of Ife, Adebisi Afolayan was instrumental in the founding of the English language department, linguistics department, language arts department, and several other associated departments and institutes at the University. He also served as the dean of the Faculty of Arts. Unlike many of his contemporaries, including Fafunwa, Oke, Afolayan is totally a-political and even though his works are read all over the world, it would be fair to characterize him as an incurably addictive home-turf intellectual. Known to refused every appointment offered him outside Nigeria, his philosophy of Confucianism quips that the best way to influence the world is to revolutionize the home base. And so, Adebisi Afolayan never took a sabbatical outside his university of practice and never accepted any political offers. His greatest contribution to-date remains his insistence on MT education and the creation of the Six-Year Yoruba Primary Project at Ile-Ife. His current institute, Centre 
for Language and Education Development (CELED), still works relentlessly on the institutionalization and standardization of Yoruba curriculum and its adoption and adaptation not only in the Yoruba community states of Nigeria but across West Africa, the model of which could apply to nations around the world.

CELED retains its location near the university campus of Ile-Ife, the same ancient city where Afolayan has lived all his university professional life.

Isaac O. Delano: Chief Isaac Oluwole Delano ${ }^{3}$ was a Nigerian Yoruba language educator who was born in the Ifo District of the Abeokuta Province on the $4^{\text {th }}$ of November, 1904. He was born to the family of Chief Edmund Delano and Rebecca Delano (both Egba indigenes). His educational exploits started from Holy Trinity Primary School situated at Okenla Christian Village in Ifo. From there, he went to Lagos Grammar School under the tutelage of an Anglican Bishop, Solomon Odutola, and his principal, Reverend E.J Evans. He transferred to Kings College in 1921, where he met with his lifetime friends and college mates; Sir Adetokunbo Ademola, Justice N.O.A Morgan as well as Dr. Ajose. Having passed his Senior Cambridge Examinations in 1923, Chief Delano proceeded to successfully write his Senior Clerical Examination in 1924, which propelled him to join the civil service in the same year. However, a severe injury sustained from an accident in 1947 led to his invalidation from the civil service. Worthy of note is the fact that he never blended into the civil service bureaucracy, as his principles and religious faith were constantly tested by various practices within the service. His dream to become more lettered was not going to succeed by his involvement with the civil service alone, and he was not positioned in those days to enjoy the privilege of travelling overseas to further his education. He had studied shorthand, and his love for writing by default made him aspire to a lifetime of authoring. While belonging to a number of literary societies, he tried his hand at writing newspaper articles which were generally well-received by the public. He was able to maintain a following from there, and this fueled his desire to write more works for public consumption; he was determined to make his mark in the field of writing. His first work as an author was published in 1936 under the title The Soul of Nigeria. This feat gave him his first taste at writing as an occupation, and the happiness that followed suit spurred him to achieve more. Isaac Delano believed that the first one was always going to be the hardest. His first published work had landed him on top of the world, and he was determined not to rest

3 Excerpt taken from the "Prologue" section of Toyin Falola's book on Delano. The Prologue is reprinted as lead essay in this journal as, "Chief Isaac Delano: The Man, His Time and His Significance." 
on his oars....When the Lutterworth Press created a popular series which was designed to motivate Africans to take to writing, titled Africa's Own Library, ... Delano's first book, The Soul of Nigeria, ... was applauded for the richness and quality of the content. Another noteworthy fact is that Isaac Delano's first book also received accolades from C.K Meek, a British anthropologist who had carved out a niche for writing about the tribes in Nigeria. Meek allegedly affirmed the contents and style with which The Soul of Nigeria was written as exhibiting quality, creativity and strict attention to detail. At a time when Africans were still yet to be involved in writing expository essays, the commendations by Meek, if they were anything to go by, represented an objective assessment.

The first book by Delano was written in 1937. Despite the wide acceptance his first book gathered, it was going to take another 11 years before he successfully published another book. After his 11-year hiatus, however, he published four books in quick succession, lending credence to his talent, hard-work and ability. Among the four books, the first one took the form of a pseudo-biography of an icon of Yoruba descent, Reverend Canon Josiah Ransome-Kuti. This work detailed aspects of Josiah Ransome-Kuti's life from his birth to his death. The major aspects documented in this book revolved around Josiah Ransome-Kuti's exploits as a songster and minister of God as well as an administrator for the British colonial government......

The second book by Isaac Delano titled The Singing Minister captured the life of Reverend Jesse Josiah Ransome-Kuti from his time in Abeokuta down to Ifo, Gbagura, and other places. Delano was able to document the problems Josiah encountered during his travels to various parts of the Yoruba country for ministration and evangelization. It also captured Josiah's time in government engagement.

In the same year, Delano published another work, An African Looks at Marriage, which was written with the conviction that it would be helpful in the growth of Christianity in Nigeria. Delano was quick to point at his naivety with respect to being qualified for what he was writing about, since there is a full Christian Ordinance that tackles matrimonial issues in Nigeria. The major note in this book was focused on bringing to the fore the marriage system that existed in the traditional and cultural realm of Nigerian societies, and the subsequent disparity with the imported marriage system that was introduced as a strong tenet of Christianity. As reported in the book, Delano affirmed meeting various church priests and bishops in the church missions in Nigeria on the issue of contrasting marriage systems in Nigeria, and how the church was determined to relegate the African marriage system to the background to favor the imported European style of marriage. Furthermore, he claimed that most of the church leadership mentioned had cause to support 
the views he discussed in the book. The concluding part of the introduction took the form of advice, as Delano hoped to convince the church authority in Nigeria and in England to understand that the marriage system imported with Christianity could weaken the church in Nigeria, making all the labor put into it become vain.

Delano's third published book in 1944, Notes and Comments from Nigeria, was dedicated to the Nigerian Youth Movement. The contents of the work reveal a compendium that spanned a period of ten painstaking years, spurred by Delano's consciousness of belonging to a race of people who had made a lot of mistakes and misdeeds in the past. He further disclosed that despite these flaws, he was proud to be a Nigerian. As part of his information-gathering process, he had cause to study in different places and at different times, while also putting his ears to the ground to get the impressions of people with respect to the subject matter.

Notes and Comments from Nigeria contained a first-person narrative of various practices in the landscape of Nigeria. It talked about the cultural heritage of some tribes as well as the religious alignments that demarcate the country into a predominantly Muslim North and a mixed, albeit liberal multi-religious South. It clearly outlined the cultural parallel that exists in the country of Nigeria. Of particular note is the practice of or early marriage between a boy and a girl in the North, a custom that is in total dissonance with the custom of the Yoruba people in the South. Bordering these two customs is the boy bride custom of the Ilorin, a practice that seems more like a hybrid of the Yoruba and Hausa marriage custom. It involved a boy that was not yet a teenager dressed as a bride, and accompanied by the bride's friends to the future husband's house. In the book, Delano also gave his view on the future of the local church in Nigeria, with particular reference to the Sacred Order of the Cherubim and Seraphim, one of the earliest local churches that infused the traditional essence of African spirituality into Christianity.

The fourth book published by Delano in 1944, establishing him as a highly rated author, was One Church for Nigeria. It was considered as a daring effort of a young man who took his religion seriously. The book contained various criticisms of the activities in the Nigeria church, as well as the inherent weaknesses he saw. This was a text that was applauded by various church leaders with respect to the advice that was contained therein. Delano asserted in One Church for Nigeria that he had waited patiently for some church leaders who he felt were better positioned than him to write against the perceived wrongs in the church. Having lost patience by not seeing any church leader doing this, he thought that it was his responsibility given by God to make these wrongs public knowledge. He believed that while a lot of individuals had knowledge of these wrongs, they had refused to face the situation squarely. He was quick 
to also place a caveat to all that his opinions should not be taken en bloc, but that they should also not embark on castigating him for bringing this issues to the fore. He asserted that he had been in mediation and careful observation of these issues for a period of ten years; hence the opinions generated are truths that he was not ashamed to point out for the growth of the Christianity in Africa.

In all, Delano brought together various perspectives of looking at Nigeria. His travels took him to Kano, Zaria, Ilorin, and Ibadan, to mention a few. His experiences are summed up into a narrative about Nigeria that are fact and true to a high degree, conveying what he gathered in his years of travelling and meeting various kinds of people. Notes and Comments from Nigeria comprise of Delano's thoughts about people and places. He was quick to place a caveat that discrepancies may exist between how he narrated his thoughts and how they are in reality. However, he ascribed that to a methodical manner of articulation that is based on providing information from observations and intuition. His passing chapter titled "The Nigerian Youth Movement" was a conscious effort to ignite the political consciousness of the youth.

Delano continued to aspire for more education, and in 1952 secured a scholarship sponsored by the British Council to further his studies at the School of Oriental and African Studies located within the University of London. It was here that Oluwole Delano met with Professor Callaghan, with whom he discussed the possibility of him publishing an English-to-Yoruba dictionary. In order for this to be possible, Callaghan advised Delano to enroll for a specialized study in order for a standard dictionary to be produced. There were little known Yoruba translations of English books as at this time, but this did not deter Isaac from trying. After all, his belief was that the first was always going to be the hardest. Having mastered the art of English writing, it was important for Isaac Delano to try his creativity in his mother tongue, Yoruba.

In 1953, Delano published İran Ò̀run (Glimpses of Heaven), a book intended to be used as a guide for teaching children in the church. Written allegorically in a similar pattern to the popular John Bunyan's $17^{\text {th }}$ century The Pilgrim's Progress, it discussed biblical morals taken from the Bible that are to serve as doctrinal content for the Christian child. The essence of this book was to inculcate the gospel message into the Christian child at a very tender age in a manner that would be understandable and clear for growing children. ...... writing his first Yoruba book, Delano had in 1934 embarked on translating the popular fiction Robinson Crusoe into the Yoruba language as part of the requirement in a literary competition. He ended up with the second prize, and this spurred him to engage in literary works in his mother tongue. 
Prior to writing Atúmọ Èdè Yorùbá, Isaac Delano, while in London to further his education, successfully completed his book Aiyé D’Aiyé Òyinbó, which can be translated into English to mean "the world had become a white man's world". The book depicts the cultural clash between the introduction of Western law and civilization against the native laws and customs in Nigeria. Published by Oxford University Press in 1954, the book was written in Yoruba, showcasing Delano's mastery and articulateness with respect to lettering his mother tongue; the Yoruba language. In the preface of this book, despite it being written in Yoruba, Delano embarked on appreciating his growing followers, deliberately calling on both his indigenous as well as non-indigenous followers. The opening chapter of Aiyé D’Aiyé Òyinbó sheds light on the travails of polygamy, in comparison to the Whiteman's adopted monogamous family settings. The settings of this chapter were his own family home, as his father was a polygamist. So, it was quite easy for him to put into writing his own experiences in a polygamous setting.

Bearing this in mind, Delano completed fundamental studies that supported the art of translation, and this led to him successfully writing Atúmọ Èdè Yorùbá and A Short Book of Yoruba Grammar and Dictionary. This was going to be the first known Yoruba dictionary which contained the translation of big Yoruba words to smaller and easy to understand content, also indicating implicit details like the part of speech, figure of speech etc., the Atúmọ Ėdè Yorùbá was widely acclaimed as the first indigenous West African language dictionary. It was published by Oxford University Press in 1960. In the same year that he published Atúmọ Ėdè Yorùbá, he also published Àgbékalẹ Ợọ Yorùbá, which is a compendium of expressions and idioms usage in the Yoruba language, bearing in mind the differences in tonal delivery of words with the same spelling that have different meanings. This is a spectacular attribute of the Yoruba language. It also contained proverbs and their proper usages, since proverbs form a significant part of the Yoruba language. In order to emphasize the import of proverbs to the Yoruba language, Delano wrote a book that was intended for students preparing for the Yoruba language in GCE. The book, (translated as "proverb is the horse on which discussion is saddled"), contained a list of 500 Yoruba proverbs and their usage as they relate to advising, reproach, and warning. The proverbs are also translated to accord the reader a perfect understanding. Other notable works by Delano that showcased his love and mastery for the Yoruba language include İránt ${ }^{\prime}$ A'n fä̀ní (Important Remembrances), which discussed the short history of important towns in Nigeria such as Lagos, Abeokuta and Oyo. He also wrote multilingual books such as Conversation in English and Yoruba, which gave some 150 conversational situations in Yoruba and their corresponding situational usages in English. This was published in 1963. Other notable works by 
the late Isaac Oluwole Delano include The Historical Events of Nigeria (containing a chronicle of the historical events in Nigeria from 1460 to 1964), A Modern Dictionary of Yoruba Usage (which highlighted the usage of Yoruba words, expressions and sentences with articles on special words, customs and traditions of the Yoruba people), as well as short biographies of Oba Akinyele and Sir Francis Ibiam, the latter withdrawn from press by the Oxford University Press due to the emergence of the Nigerian Civil War.

The Late Chief (Dr.) Isaac Oluwole Delano also contributed immensely to the growth of Yoruba studies in tertiary institutions in Nigeria. In 1963, he was invited to the University of Nigeria, Nsukka (UNN), to assist in developing the institution's language and linguistics department (with special reference to Yoruba), where his work resulted in him being loved and revered by students and staff alike. His stay at UNN afforded him the responsibility of mentoring and advising the Yoruba community in the institution. However, his time in Nsukka was cut short as a result of the Nigerian Civil War. Not resting on his laurels, he contacted the administration of the University of Ife, where the late Professor Ezekiel Oluwasanmi welcomed him by offering him a job as a lecturer at the Institute of African Studies. This would later accord him the opportunity of working with Professor Agboola Akinjogbin, with whom he later developed a very cordial relationship. Suffice it to say that his time in Ife happened to be the most appreciated, as the authorities of the institution honoured him with the honor of Doctor of Letters (D.Litt.) in the presence of icons such as Chief Obafemi Awolowo, Chief Akintola Williams, Justice Abina and Ola Rotimi. Chief Isaac Oluwole Delano died on December 15, 1979.

Francis Abiola Irele: Although of Edo ancestry, Abiola Irele was born in Igbo Ora, Oyo State on May 22, 1936. Known as the very first Nigerian professor of modern European languages, his specialization was in literary criticism and systemic text linguistics. Irele was a polyglot to the core with ability to read, write and speak multiple languages, including English, French, Yoruba, Igbo, Ora and Edo. Earlier in life, he lived in Enugu, and consequently was exposed to the Igbo language and culture but indeed, his first language of fluency was Igbo, not so much because of having lived in Enugu but because he learned to speak the language while in Lagos through his father's house help who also doubled as his caretaker at the age of four, technically making Igbo language Irele's first language. It was not until 1943 that a family breakup forced him to accompany his mother to her natal home of Ora (no relationship to Igbo Ora, where he was born), where he learned to speak the local language of Ora as well. His knowledge of Yoruba did not take serious shape until when he returned to Lagos to live with his father about the age of eight. 
Irele was among the earlier waves of Nigerian students of the nation's premier University of Ibadan, which then was the University College of London. He graduated in 1960 after which he traveled to Paris to study French language and literature at the University of Paris, Sorbonne, obtaining a $\mathrm{PhD}$ degree in 1966. He immediately returned to Nigeria and joined the Languages Faculty at the University of Lagos before proceeding to Legon University, Ghana. He moved to the University of Ife in the mid-1980s and later worked at the University of Ibadan. In 1989, Irele migrated to the United States, joining the Ohio State University as Professor of African, French, and Comparative Literature.

Literature, especially oral literature, became Abiola Irele's passion from early in life when he was exposed to folktales and other forms of oral traditions. He accompanied many oral artists in the street and became fascinated with the rárà performance. That was how he acquired his first form of education predating his exposure to the formal western education. Speculatively, then, the conflicting and dilemmatic scenario of the crossroad that the African writer enters in the ability (or disability) to express and be understood even by his or her own people when writing in a European language must be one of the philosophical justifications for Irele to see the light and embrace the reality of an indigenous language of learning where a problem of mutual understanding is not at stake. Irele speaks to this issue, in his well-circulated book, The African Experience in Literature and Ideology: ${ }^{4}$

...The situation of the African writer is thus quite different. His problem lies in the fact that however intimate his relationship to the European language, there is always the pressure upon him, in addition to the normal demands of artistic creation, to bridge that distance between the African world and the European language. The point at issue here is not whether an African can successfully write in English or French - we have enough evidence that that particular issue is resolved - but whether in the present circumstances, the work that he produces can have a meaning for his African audience (pp.54-55).

Henry-Louis Gates, Jr. is, in a way, in solidarity with Irele's position, as he speaks to the same dilemma of sub classification of the works of the African American writers, as different from the mainstream Western writings.

4 See Abiola Irele, The African Experience in Literature and Ideology, London: Heinemann, 1981. 
In The Signifying Monkey: A Theory of African-American Literary Criticism, he quips: ${ }^{5}$

It is probably true that critics of African and Afro-American literature were trained to think of the institution of literature essentially as a set of Western texts. The methods devised to read these texts are culture-specific and temporal-specific, and text-specific as well...

In essence, one of the dilemmas of Western culture of intellection and pedagogical tools of language that brought Abiola Irele to the realization of the need for an indigenous knowledge base in mother-tongue education is almost the same that Gates accentuates in his own experience of African Americans writing in the mainstream English language.

Before his return home to Nigeria, Irele was a Visiting Professor of African and African American Studies and of Romance Languages and Literatures at Harvard University, and this would be his final overseas intellectual professional engagement. On his return to Nigeria, he joined the newly formed Kwara State University, Malete, where he was appointed the Provost for one of the colleges in the institution. This, too, would be his final professional engagement in Nigeria before returning to the United States for medical reasons. Francis Abiola Irele died on July 2, 2017.

We have highlighted the backgrounds of these four key players of the MTE experiment at the University of Ife for three reasons: First, because they are individuals whose life stories are easily available and accessible to us as of the time of this writing. Secondly, it is to further underscore the fact that there is a connection between experience and practical applications. Thirdly, and finally, the lives of these four men constitute an empirical proof that the Six-Year Primary Project of the Yoruba Mother-Tongue Education was a deliberate professional venture precipitated by the need to demonstrate the authenticity and effectiveness of indigenous knowledge acquisition and production.

\section{References}

Afolayan, Adebisi, "The Linguistics Problem of Yoruba Learners and Users of English,"Unpublished PhD Thesis, London, 1968.

Afolayan, A. (2001). "The alienated role of the mother tongue in literacy education for sustainable national development: The Western Nigeria Yoruba example." In S. Manaka (Ed.), Proceedings of the first Pan-African reading

5 See Henry-Louis Gates, Jr., The Signifying Monkey: A Theory of African-American Literary Criticism. New York, Oxford University Press, 1988. 
for all conference, Pretoria, South Africa (pp. 70-88). Pretoria, South Africa: International Reading Association.

Fafunwa, A. B., J.I. Macauley, and J.A.F. Sokoya. (Eds.). Education in Mother Tongue: The Ife Primary. Education Research Project. Ibadan: University Press Limited, 1989.

Faundez, Antonion, and Paulo Freire. Learning to Question: A Pedagogy of Liberation. Trans. Tony Coates, New York, Continuum, 1992.

Fischer, Marilyn, 2013, "Reading Dewey's Political Philosophy through Addams's Political Compromises", American Catholic Philosophical Quarterly, 87.2 (2013): 227-243.

Freire, P. and A.M.A. Freire. Pedagogy of Hope: Reliving Pedagogy of the Oppressed. New York, Continuum, 1994.

Freire, P. Mentoring the Mentor: A Critical Dialogue with Paulo Freire. New York: Peter Lang, 1997.

Freire, P. and A.M.A. Freire. Pedagogy of the Heart. New York, Continuum, 1997.

Gates, H-L Henry-Louis Gates, Jr., The Signifying Monkey: A Theory of African-American

Literary Criticism: New York: Oxford University Press, 1988.

Hallmarks of Labor Foundation, Prof. Aliu Babatunde Fafunwa: Hallmarks of Labor Role Model Award: https://hallmarksoflabour.org/citations/ prof-aliu-babatunde-fafunwa-nnom-con-hlr/.

Irele, F. Abiola. The African Experience in Literature and Ideology. Indiana University Press, 1990.

Irele, F. Abiola. The African Experience in Literature and Ideology. London: Heinemann, 1981.

Irele, F. Abiola. The African Imagination: Literature in Africa and the Black Diaspora. Oxford University Press, 2001.

Na'Allah, Abdul-Rasheed. "Literature, Culture and Thought in Africa: A Conversation with Abiola Irele.” West Africa Review, Issue 7 (2005): 17-32.

Savory, E. (2009). "An interview with Francis Abiola Irele". Wadabagei: A Journal of the Caribbean and its Diaspora. 12.1 (2009): 109-132.

Shook, John R. Dewey's Empirical Theory of Knowledge and Reality. Nashville, TN: Vanderbilt University Press, 2000. 